\title{
Desensitization and Tolerance of Mu Opioid Receptors on Pontine Kölliker-Fuse Neurons
}

\author{
Erica S. Levitt and John T. Williams \\ Department of Pharmacology and Therapeutics, University of Florida, Gainesville, Florida (E.S.L.) and Vollum Institute, Oregon \\ Health and Science University, Portland, Oregon (J.T.W.)
}

Received June 9, 2017; accepted October 25, 2017

\section{ABSTRACT}

Acute desensitization of mu opioid receptors is thought to be an initial step in the development of tolerance to opioids. Given the resistance of the respiratory system to develop tolerance, desensitization of neurons in the Kölliker-Fuse (KF), a key area in the respiratory circuit, was examined. The activation of $G$ protein-coupled inwardly rectifying potassium current was measured using whole-cell voltage-clamp recordings from KF and locus coeruleus (LC) neurons contained in acute rat brain slices. A saturating concentration of the opioid agonist $\left[\mathrm{Met}^{5}\right]$-enkephalin (ME) caused significantly less desensitization in KF neurons compared with LC neurons. In contrast to LC, desensitization in KF neurons was not enhanced by activation of protein kinase $C$ or in slices from morphine-treated rats. Cellular tolerance to ME and morphine was also lacking in KF neurons from morphine-treated rats. The lack of cellular tolerance in KF neurons correlates with the relative lack of tolerance to the respiratory depressant effect of opioids.

\section{Introduction}

The incidence of prescription opioid overdose has been increasing at a rapid rate in the United States (Centers for Disease Control and Prevention, 2016; Rudd et al., 2016). The primary cause of death from opioid overdose is respiratory depression. The mu opioid receptor is responsible for both the analgesic and respiratory depressant effects caused by morphine (Matthes et al., 1996; Dahan et al., 2001). Individuals at risk of overdosing on opioids are those using large doses due to the development of tolerance to the desired effect (analgesia or euphoria), while tolerance to the respiratory depressant effect develops less readily (Ling et al., 1989; Paronis and Woods, 1997; Athanasos et al., 2006; Emery et al., 2016; Hill et al., 2016).

The development of opioid tolerance is likely a multistep process involving many pathways (Williams et al., 2013). Desensitization of the opioid receptor itself is thought to be an initial step in the development of tolerance, but to date there is no concrete evidence linking the two processes. Most of what is known about the process of desensitization of endogenous, somatodendritic mu opioid receptors comes from locus coeruleus (LC) neurons (Harris and Williams, 1991; Alvarez et al., 2002; Blanchet and Lüscher, 2002; Bailey et al., 2004, 2009a,b; Virk and Williams, 2008; Quillinan et al., 2011; Arttamangkul et al., 2012; Dang et al., 2012; Williams, 2014; Lowe et al., 2015). A 5-10-minute exposure to saturating concentrations of opioid agonists leads to a reduction in the

This work was supported by the National Institutes of Health National Institute on Drug Abuse [Grants R01 DA08163 and K99/R00 DA038069].

http://doi.org/10.1124/mol.117.109603. activation of $\mathrm{G}$ protein-coupled inwardly rectifying potassium (GIRK) conductance. Given that tolerance to respiratory depressant effects of opioids is less than to antinociceptive effects, mu opioid receptors on neurons of the central respiratory network may not desensitize. In the present study, this hypothesis was tested by measuring desensitization and tolerance of mu opioid receptors on Kölliker-Fuse (KF) neurons using whole-cell voltageclamp recordings in rat brain slices.

The KF is located in the pontine pneumotaxic center and controls upper airway patency and regulates respiration, in particular the inspiratory/expiratory phase transition. Activation of mu opioid receptors in the KF leads to a reduction in respiratory rate in anesthetized animals (Prkic et al., 2012; Levitt et al., 2015) and disrupts the inspiratory/expiratory phase transition in arterially perfused preparations of rat (Levitt et al., 2015). Mu opioid receptors on KF neurons activate GIRK conductance (Levitt et al., 2015), which was used to examine acute desensitization and tolerance. Acute desensitization in $\mathrm{KF}$ and LC neurons was compared under identical experimental conditions. Tolerance in KF neurons was measured in brain slices from rats that were treated chronically with morphine using a dosing paradigm that produces tolerance in LC neurons (Quillinan et al., 2011; Levitt and Williams, 2012). The results show that opioid-sensitive neurons in the KF displayed less desensitization and did not develop long-term tolerance.

\section{Materials and Methods}

Ethical Approval. Animal experiments were conducted in accordance with the National Institutes of Health guidelines and with

ABBREVIATIONS: ACSF, artificial cerebrospinal fluid; ANOVA, analysis of variance; CGP55845, XXX; DNQX, 6,7-dinitroquinoxaline-2,3-dione; GIRK, G protein-coupled inwardly rectifying potassium; KF, Kölliker-Fuse; LC, locus coeruleus; ME, [Met ${ }^{5}$ ]-enkephalin; MK801, (5S,10R)-(+)-5Methyl-10,11-dihydro-5H-dibenzo[a,d]cyclohepten-5,10-imine maleate; PDBu, phorbol 12,13-dibutyrate; PKC, protein kinase C; POMC, proopiomelanocortin; VTA, ventral tegmental area. 
approval from the Institutional Animal Care and Use Committee of the Oregon Health and Science University (Portland, OR).

Animals. Rats $(n=110$ total, Sprague-Dawley, male, 4-7 weeks old; Charles River Laboratories, Wilmington, MA) were used for all experiments. Seventeen rats were treated with morphine sulfate continuously released from osmotic pumps as described previously (Levitt and Williams, 2012). Five rats were implanted with pumps containing vehicle (water) alone. Osmotic pumps (2ML1; Alzet, Cupertino, CA) were filled with the required concentration of morphine sulfate in water to deliver $50 \mathrm{mg} / \mathrm{kg}$ per day. Each $2 \mathrm{ML} 1$ pump has a $2-\mathrm{ml}$ reservoir that releases $10 \mu \mathrm{l} / \mathrm{h}$ for up to 7 days. Rats were anesthetized with isoflurane, and an incision was made in the midscapular region for subcutaneous implantation of osmotic pumps. Pumps remained until animals were used for experiments 6 or 7 days later. This dosing paradigm produces tolerance in LC neurons (Quillinan et al., 2011; Levitt and Williams, 2012).

Brain Slice Electrophysiology. Recording conditions and acute brain slice preparation was performed as described previously (Levitt and Williams, 2012; Levitt et al., 2015). Rats (Sprague-Dawley, male, 4-7 weeks) were killed and the brain was removed, blocked, and mounted in a vibratome chamber (Leica VT1200 S; Leica Biosystems, Buffalo Grove, IL). Horizontal (LC or KF) or coronal (KF) slices $(240 \mu \mathrm{m})$ were prepared in ice-cold artificial cerebrospinal fluid (ACSF) containing the following (in millimolar): $126 \mathrm{NaCl}, 2.5 \mathrm{KCl}$, $1.2 \mathrm{MgCl}_{2}, 2.6 \mathrm{CaCl}_{2}, 1.2 \mathrm{NaH}_{2} \mathrm{PO}_{4}, 11$ D-glucose, and $21.4 \mathrm{NaHCO}_{3}$ (equilibrated with $95 \% \mathrm{O}_{2} / 5 \% \mathrm{CO}_{2}$ ). Slices were stored at $32^{\circ} \mathrm{C}$ in glass vials with oxygenated $\left(95 \% \mathrm{O}_{2} / 5 \% \mathrm{CO}_{2}\right)$ ACSF. (5S,10R)-(+)-5-Methyl10,11-dihydro-5H-dibenzo[a,d]cyclohepten-5,10-imine maleate (MK801) $(10 \mu \mathrm{M})$ was included in the cutting and initial incubation solution to block N-methyl-D-aspartate (NMDA) receptor-mediated excitotoxicity. After an incubation period of at least 30 minutes, slices were hemisected and transferred to a recording chamber which was perfused with $34^{\circ} \mathrm{C}$ $\operatorname{ACSF}\left(95 \% \mathrm{CO}_{2} / 5 \% \mathrm{O}_{2}\right)$ at a rate of $1.5-3 \mathrm{ml} / \mathrm{min}$.

Coronal and horizontal brain slices containing KF were used. Opioid-mediated currents and intrinsic cell properties are similar for KF neurons in coronal and horizontal slices (Levitt et al., 2015). The location of KF neurons in coronal and horizontal slices was consistent with the rat brain atlas (Paxinos and Watson, 1998). KF neurons with an opioid-mediated outward current ( $60 \%$ of $\mathrm{KF}$ neurons) fired action potentials with slower frequency after injection of current steps (50-250 pA, 2 seconds) and had smaller-amplitude afterhyperpolarization (Levitt et al., 2015).

Whole-cell recordings were made from $\mathrm{LC}$ and $\mathrm{KF}$ neurons with an Axopatch 1D amplifier (Molecular Devices, Sunnyvale, CA) in voltageclamp mode $\left(\mathrm{V}_{\text {hold }}=-60 \mathrm{mV}\right)$. Recording pipettes $(1.5-2.2 \mathrm{M} \Omega$ ) were filled with internal solution containing the following (in millimolar): 115 potassium methanesulfonate, $20 \mathrm{NaCl}, 1.5 \mathrm{MgCl}_{2}, 5$ HEPES(K), 2 BAPTA (1,2-bis(o-aminophenoxy)ethane-N,N, $\mathrm{N}^{\prime}, \mathrm{N}^{\prime}$-tetraacetic acid), $2 \mathrm{Mg}$-ATP, $0.2 \mathrm{Na}$-GTP, $\mathrm{pH} 7.4,275-280 \mathrm{mOsM}$. Liquid junction potential $(10 \mathrm{mV})$ was not corrected. Data were filtered at $10 \mathrm{kHz}$ and collected at $20 \mathrm{kHz}$ with AxographX or $400 \mathrm{~Hz}$ with PowerLab (Chart version 5.4.2; AD Instruments, Colorado Springs, CO). Series resistance was monitored without compensation and remained $<15 \mathrm{M} \Omega$ for inclusion.

Drugs [including $\left[\mathrm{Met}^{5}\right]$-enkephalin acetate salt (ME), morphine, naloxone, baclofen, and CGP55845 ((2S)-3-[[(1S)-1-(3,4-Dichlorophenyl)ethyl]amino-2-hydroxypropyl](phenylmethyl)phosphinic acid hydrochloride)] were applied by bath perfusion at the indicated concentrations. Bestatin $(10 \mu \mathrm{M})$ and thiorphan $(1 \mu \mathrm{M})$ were included with ME to prevent degradation.

Drugs. ME, bestatin HCl, D,L-thiorphan, ( \pm )-baclofen, and phorbol 12,13-dibutyrate (PDBu) were from Sigma-Aldrich (St. Louis, MO). Morphine sulfate and morphine alkaloid were obtained from the National Institute on Drug Abuse Neuroscience Center (Bethesda, MD). Naloxone and MK801 were from Abcam (Cambridge, MA). CGP55845 was from Tocris (Minneapolis, MN).

Data Analysis. Statistical analysis was performed using GraphPad Prism 6.0f software (GraphPad Software, La Jolla, CA). Values are presented as the mean \pm S.E.M. Recordings were made from one neuron per slice with one to two slices per animal. Data sets with $n>8$ were tested for normality using the D'Agostino-Pearson normality test. Nonparametric statistical tests were used if one data set of a comparison failed the normality test and was not well fit by a Gaussian frequency distribution. Comparisons between two values were made using two-tailed $t$ test or Mann-Whitney test. Comparisons of three or more values were made with one-way analysis of variance (ANOVA) and Tukey's multiple comparisons test or KruskalWallis test and Dunn's multiple comparisons test. Comparisons between two groups with two or more values per group were made using two-way ANOVA and Sidak's multiple comparisons test. Plateau values were from one-phase decay nonlinear fit of data from each neuron. Statistical tests used are listed in the figure legends or in the text. Comparisons with $P<0.05$ were considered significant.

\section{Results}

Acute Desensitization of Opioid Receptors on KF and LC Neurons. Whole-cell voltage-clamp recordings were made from $\mathrm{KF}$ and $\mathrm{LC}$ neurons in acute rat brain slices. The opioid agonist ME produced an outward current in $\mathrm{KF}$ and LC neurons, which is mediated by activation of GIRK conductance (Torrecilla et al., 2002; Levitt et al., 2015). A saturating concentration of $\mathrm{ME}(30 \mu \mathrm{M})$ induced a current that was $80 \pm 6 \mathrm{pA}(2.4 \pm 0.1 \mathrm{pA} / \mathrm{pF} ; n=38)$ in $\mathrm{KF}$ neurons and $356 \pm 28 \mathrm{pA}(5.2 \pm 0.6 \mathrm{pA} / \mathrm{pF} ; n=14)$ in $\mathrm{LC}$ neurons. In both LC and KF, the current produced by ME is due to activation of mu opioid receptors rather than delta opioid receptors (Williams and North, 1984; Levitt et al., 2015).

Acute desensitization of the opioid-mediated GIRK current was evaluated using two measures, which may be mediated by different processes (Birdsong et al., 2015). The first measure was the decline in current that occurred during an 8-minute continuous application of a saturating concentration of $\mathrm{ME}$ $(30 \mu \mathrm{M})$. The second measure was the reduction in the current produced by a subsaturating concentration of ME (300 nM) that was applied as a probe before and 10 minutes after washout of the saturating concentration of $\mathrm{ME}(30 \mu \mathrm{M})$.

During an 8-minute application of $\mathrm{ME}(30 \mu \mathrm{M})$ ) the current declined in both LC and KF neurons (Fig. 1, A and B). At the end of the application, the current had declined significantly less in KF neurons compared with LC neurons [Fig. 1C; $\mathrm{KF}=28 \% \pm 1.4 \%$ decline $(n=21) ; \mathrm{LC}=44 \% \pm 2.7 \%$ decline $(n=13) ; P<0.0001$, unpaired $t$ test]. When the data were normalized to the peak and fit to a single exponential, the half-life was less for $\mathrm{KF}$ (1.6 \pm 0.2 minutes; $n=10)$ compared with LC $(2.5 \pm$ 0.3 minutes; $n=11 ; P=0.0297$, unpaired $t$ test), and the plateau of the decay curve was significantly less desensitized for KF neurons $(65.2 \% \pm 4.5 \%$ of peak; $n=10)$ compared with LC neurons $(46.0 \% \pm 4.3 \%$ of peak; $n=11$; $P=0.0061$, unpaired $t$ test). The data became significantly different 5 minutes into perfusion of ME $(30 \mu \mathrm{M})$ (Fig. 1D; $P<0.05$, repeated-measures two-way ANOVA and Sidak post-test). The half-life and plateau values for $\mathrm{LC}$ were similar to previously reported values [half-life $=2.3$ minutes $(95 \%$ confidence interval 2.0-2.7 minutes); plateau $=36.2 \% \pm 1.6 \%$ $(P=0.2058$, unpaired $t$ test)] (Bailey et al., 2003).

Since the amplitude of currents was smaller in KF neurons, the correlation between current amplitude and degree of desensitization was examined. The amount of decline in $\mathrm{KF}$ neurons was not correlated with the amplitude of current [Fig. $1 \mathrm{E}$; slope of linear regression $(1.4 \pm 1.4 \mathrm{pA} / \%$ decline $)$ did not significantly deviate from zero $(P=0.314)]$. The decline was 


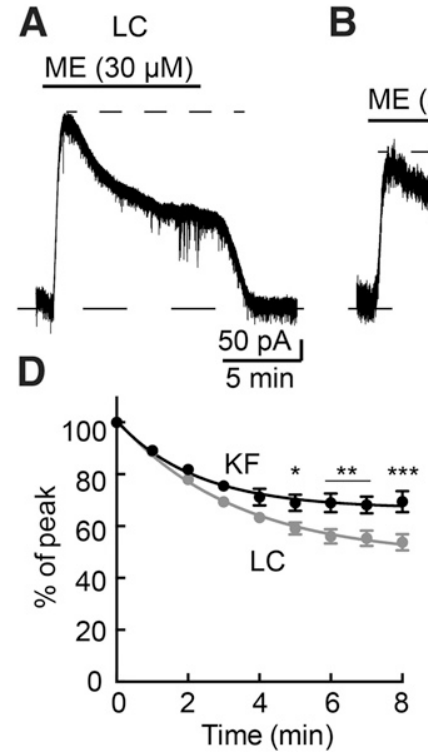

$\mathrm{KF}$

\section{$(30 \mu \mathrm{M})$}

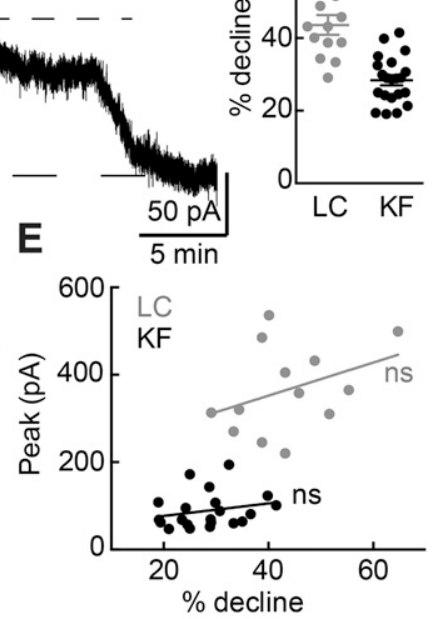

Fig. 1. Decline in peak ME current was less in KF neurons. Whole-cell voltage-clamp recording from $\mathrm{LC}(\mathrm{A})$ or $\mathrm{KF}(\mathrm{B})$ neuron in brain slice. Opioid agonist $\mathrm{ME}(30 \mu \mathrm{M})$ was applied by bath perfusion. (C) Summary of decline in ME-mediated (30 $\mu \mathrm{M})$ current measured at the end of 7-9 minutes of ME perfusion. Line and error are the mean \pm S.E.M. Scatter shows the individual data points (one neuron per slice). $* * * P<0.0001$, unpaired $t$ test. (D) Summary of ME-mediated $(30 \mu \mathrm{M})$ current, each minute normalized to the peak in $\mathrm{LC}$ and $\mathrm{KF}$ neurons. KF declined less [repeatedmeasures two-way ANOVA: interaction $\mathrm{F}_{(8,152)}=7.020, P<0.0001$; treatment $\mathrm{F}_{(1,19)}=7.532, P=0.0129 ; * P<0.05 ; * * P<0.01$; *** $P<0.0001$, Sidak post-test; $n=11(\mathrm{LC})$ and $10(\mathrm{KF})]$. Points and error are the mean \pm S.E.M. Data were fit to a single exponential. (E) In LC and KF neurons, correlation between the amount of decline (percentage) and peak ME-mediated (30 $\mu \mathrm{M})$ current (pA) was not significant (ns; LC, slope of linear regression $=3.8 \pm 2.9 \mathrm{pA} / \%$ decline, $P=0.215 ; \mathrm{KF}$, slope of linear regression $=1.4 \pm 1.4 \mathrm{pA} / \%$ decline, $P=0.314)$. Each data point is from a single cell in a separate slice.

also not correlated with amplitude in LC neurons [slope of linear regression $(3.8 \pm 2.9 \mathrm{pA} / \%$ decline $)$ did not significantly deviate from zero $(P=0.215)]$.

The second measure of desensitization was to use a subsaturating concentration of $\mathrm{ME}(300 \mathrm{nM})$ as a probe before and 10 minutes after exposure to the saturating concentration of ME. This second measure is a sensitive assay since $\mathrm{ME}(300 \mathrm{nM})$ is on the steep part of the ME concentration-response curve. ME $\left(300 \mathrm{nM}\right.$ ) is near the $\mathrm{EC}_{50}$ in both $\mathrm{LC}$ and $\mathrm{KF}$ neurons (Quillinan et al., 2011; Levitt et al., 2015). The ratio of current produced by $300 \mathrm{nM}$ and $30 \mu \mathrm{M} \mathrm{ME}$ was used to approximate the sensitivity of mu opioid receptors on individual neurons. This ratio was $61 \% \pm$ $3 \%$ for LC neurons and $62 \% \pm 3 \%$ for KF neurons. Repeated application of ME (300 nM; 5-30 minutes apart) produced currents with similar amplitude in KF neurons $[101 \% \pm 3 \%$ of the first application $(n=18) ; P=0.6614$, paired $t$ test].

In LC neurons, the current produced by ME $(300 \mathrm{nM})$ was robustly reduced ( $32 \% \pm 4 \%$ of pre-desensitized; $n=9$ ) when tested 10 minutes after an 8-minute application of a desensitizing concentration of ME (Fig. 2, A and C). In KF neurons, the current produced by ME (300 $\mathrm{nM})$ was significantly less affected ( $68 \% \pm 2 \%$ of pre-desensitized; $n=18) 10$ minutes following application of a desensitizing concentration of $\mathrm{ME}$ (Fig. 2, B and C; $P<0.0001$, unpaired $t$ test).

There was no correlation between the amplitude of current (ME peak) and the reduction of ME (300 $\mathrm{nM})$ probe current (percentage of pre-desensitized) in $\mathrm{KF}$ or LC [Fig. 2D; KF,

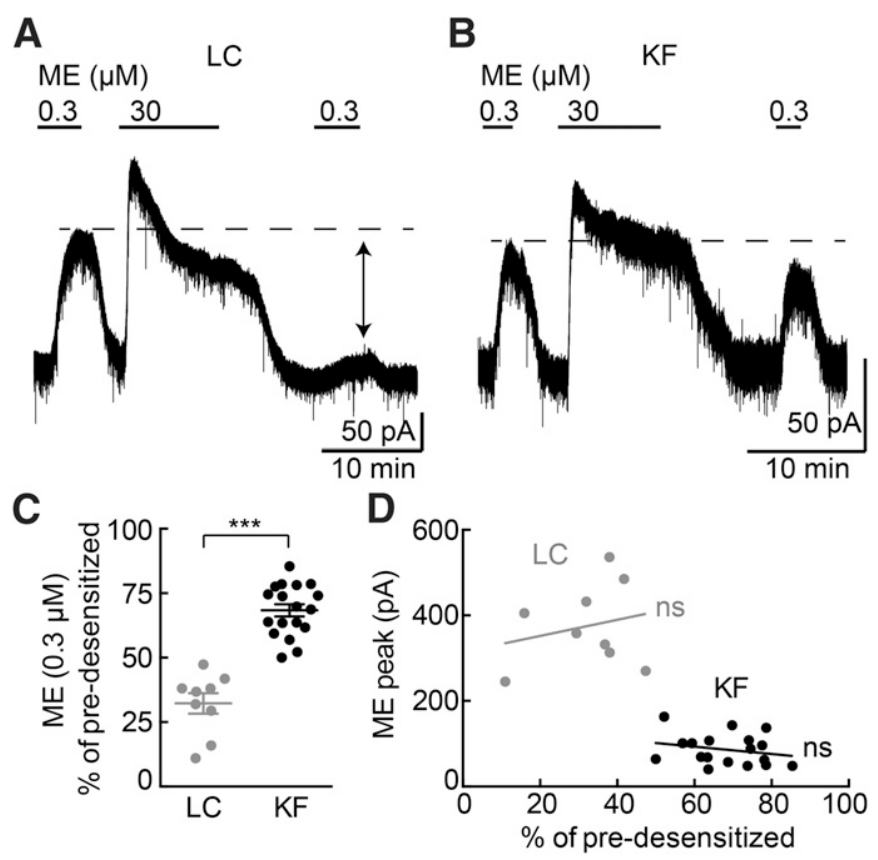

Fig. 2. Desensitization of ME-mediated (300 nM) current was less in $\mathrm{KF}$ neurons. Whole-cell voltage-clamp recording from LC (A) or KF (B) neuron in brain slice. $\mathrm{ME}(0.3 \mu \mathrm{M})$ was bath perfused before and 10 minutes following application of ME (30 $\mu \mathrm{M}, 7-9$ minutes). (C) Summary of the current produced by $\mathrm{ME}(0.3 \mu \mathrm{M})$ after desensitization normalized to the current produced by $\mathrm{ME}(0.3 \mu \mathrm{M})$ before desensitization. Line and error are the mean \pm S.E.M. Scatter shows the individual data points (one neuron per slice). $* * * P<0.0001$, unpaired $t$ test. (D) Correlation between the reduction of $\mathrm{ME}(0.3 \mu \mathrm{M})$ current (percentage of pre-desensitized) and peak ME-mediated (30 $\mu \mathrm{M})$ current (pA) was not significant (ns; slope of linear regression $=-0.85 \pm 0.87 \mathrm{pA} / \%$ prepulse, $P=0.3428$ ). Each data point is from a single cell in a separate slice.

slope of linear regression $=-0.85 \pm 0.87 \mathrm{pA} / \%$ (not significantly different from zero, $P=0.3428$ ); LC, slope of linear regression $=1.88 \pm 3.01 \mathrm{pA} / \%$ (not significantly different from zero, $P=0.5517)]$. For both LC and KF, there was no correlation between the amount of desensitization measured with prolonged application and the probe concentration, indicating that these two assays are independent measures [LC, slope of linear regression $=-0.20 \% \pm 0.19 \%$ of probe $/ \%$ decline $(P=0.336)$; $\mathrm{KF}$, slope of linear regression $=-0.24 \% \pm 0.37 \%$ of probe $/ \%$ decline $(P=0.5271)]$. Thus, using two measures, there was less desensitization in KF neurons than in LC neurons.

Recovery from Desensitization. To measure recovery from desensitization, the $\mathrm{ME}(300 \mathrm{nM})$ probe was applied at 10, 20, and 30 minutes following desensitization (Fig. 3A). The small reduction of probe current observed in KF neurons partially recovered over the course of 30 minutes, reaching $83 \% \pm 7 \%(n=7)$ of the initial amplitude (Fig. 3C). This is unlike the $\mathrm{LC}$, in which the probe current recovered to 60\%-70\% of the initial amplitude after 30 minutes (Quillinan et al., 2011; Levitt and Williams, 2012).

Modulation by Protein Kinase C. In LC neurons, activation of protein kinase $\mathrm{C}(\mathrm{PKC})$ enhanced the decline in current induced by a saturating concentration of $\mathrm{ME}(30 \mu \mathrm{M})$ (Bailey et al., 2004). To investigate this in KF neurons, PKC was activated by including the phorbol ester PDBu $(100 \mathrm{nM})$ in the perfusion solution for 10 minutes prior to and throughout the experiment. PDBu caused a robust increase in spontaneous synaptic currents, which were blocked by the AMPA 
A $\mathrm{ME}(\mu \mathrm{M})$

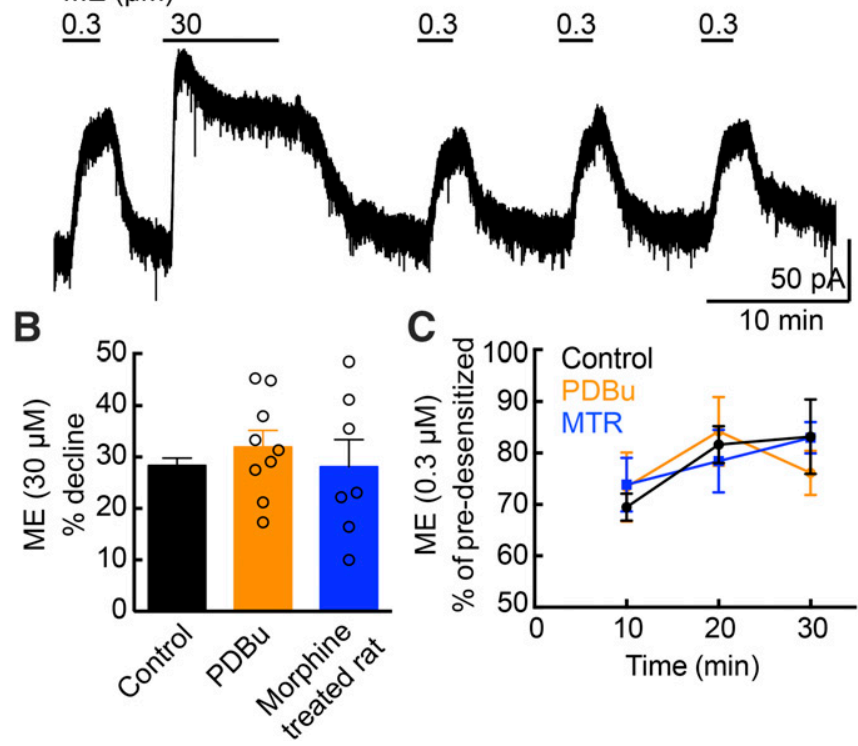

Fig. 3. Manipulations that enhance desensitization fail in KF. (A) Wholecell voltage-clamp recording from a KF neuron in control brain slice. ME $(0.3 \mu \mathrm{M})$ was perfused before and 10,20 , and 30 minutes following application of $\mathrm{ME}$ ( $30 \mu \mathrm{M}, 7-9$ minutes). Experiments using untreated slices from naïve rats (control) were compared with slices from naïve rats treated with $\mathrm{PKC}$ activator PDBu (100 nM) or slices from morphine-treated $(50 \mathrm{mg} / \mathrm{kg}$ per day, 6-7 days) rats (MTR). (B) Summary of the decline of the ME-treated (30 $\mu \mathrm{M})$ current in KF neurons. Control data are repeated from Fig. 1C. Decline was not different from control for either manipulation $(P>0.05$, one-way ANOVA and Tukey post-test). Line and error are the mean \pm S.E.M. Scatter show individual data points (one neuron per slice). (C) Recovery of ME-treated $(0.3 \mu \mathrm{M})$ currents in control slices, PDBu-treated slices, and slices from morphine-treated rats was not different [two-way ANOVA: PDBu vs. control, $\mathrm{F}_{(1,43)}=0.001, P=0.9719 ;$ morphine-treated rat vs. control, $\mathrm{F}_{(1,46)}=0.006$, $P=0.9405]$. Data are the mean \pm S.E.M. $(n=3-17)$.

and GABA-A blockers DNQX (6,7-dinitroquinoxaline-2,3-dione; $10 \mu \mathrm{M})$ and gabazine $(1 \mu \mathrm{M})$, respectively. The decline in current during application of $\mathrm{ME}$ ( $30 \mu \mathrm{M}, 8$ minutes) was not affected by $\mathrm{PDBu}$ [Fig. 3B; $\mathrm{PDBu}=32 \% \pm 3.2 \%(n=9)$ vs. untreated $=$ $28 \% \pm 1.4 \%(n=21) ; P=0.2399$, unpaired $t$ test].

The current produced by $\mathrm{ME}(300 \mathrm{nM})$ was significantly reduced following perfusion of $\mathrm{PDBu}$ (100 nM, 10 minutes, $72 \% \pm 3 \%$ of baseline; $n=10 ; P<0.0001$, paired $t$ test). However, the ratio of the current produced by $\mathrm{ME}(300 \mathrm{nM})$ relative to the saturating concentration of $\mathrm{ME}(30 \mu \mathrm{M})$ was unchanged by $\mathrm{PDBu}$ treatment [untreated $=61.5 \% \pm 2.9 \%(n=20) ; \mathrm{PDBu}=59 \% \pm$ $4 \%(n=12) ; P=0.5506$, unpaired $t$ test]. This indicates that the reduction in current produced by $\mathrm{PDBu}$ is downstream of activation of the opioid receptor by agonist.

The desensitization protocol was then performed with PDBu (100 nM) included in the perfusion solution. Desensitization measured at 10 minutes using $\mathrm{ME}(300 \mathrm{nM})$ as a probe was unaffected by PDBu treatment $[67 \% \pm 3 \%(n=6)$ of predesensitized, compared with $68 \% \pm 2 \%(n=18)$ of predesensitized in untreated slices; Fig. $3 \mathrm{C} ; P=0.7728$, unpaired $t$ test]. Recovery from this small amount of desensitization over 30 minutes was not different from control [Fig. 3C; $n=4$; two-way ANOVA: $\left.\mathrm{F}_{(1,43)}=0.00126, P=0.9719\right]$.

Modulation by Chronic Morphine Treatment. Decline of the current produced by a saturating concentration of $\mathrm{ME}$ $(30 \mu \mathrm{M})$ in LC neurons is enhanced in slices from morphinetreated rats (Dang and Williams, 2004; Quillinan et al., 2011). To determine if decline was enhanced in $\mathrm{KF}$ neurons, rats were treated with morphine ( $50 \mathrm{mg} / \mathrm{kg}$ per day) continuously released from osmotic pumps for 6-7 days. Brain slices from morphine-treated rats were incubated in morphine-free solution for at least 2 hours to allow morphine to wash from the slice (Levitt and Williams, 2012). The decline in current produced by the saturating concentration of ME $(30 \mu \mathrm{M})$ was not different from untreated rats (Fig. 3B; morphine-treated $=28 \% \pm 5 \%[n=7]$ vs. untreated $=28 \% \pm 1 \%$ [ $n=21] ; P=0.9442$, unpaired $t$ test). These results were unlike what has been reported in the LC where the decline was greater after chronic morphine treatment (control $=35 \% \pm 2 \%$ decline; morphine-treated $=47 \% \pm 2 \%$ decline) (Quillinan et al., 2011).

The recovery from desensitization is significantly attenuated in LC neurons in slices from morphine-treated rats (Dang and Williams, 2004; Quillinan et al., 2011). The recovery from desensitization in KF neurons was measured in slices from morphine-treated rats using $\mathrm{ME}(300 \mathrm{nM})$ as a probe before and 10,20, and 30 minutes after an 8-minute application of a saturating concentration of $\mathrm{ME}(30 \mu \mathrm{M})$. The current produced by $\mathrm{ME}(300 \mathrm{nM})$ at 10 minutes was $74 \% \pm 5 \%(n=9)$ of the predesensitized current, which was not different from experiments with untreated rats (Fig. 3C; untreated rats $=68 \% \pm 2 \%$ of pre-desensitized [ $n=18] ; P=0.2740$, unpaired $t$ test). The current produced by $\mathrm{ME}(300 \mathrm{nM})$ recovered over the course of 30 minutes similar to experiments with untreated rats (Fig. 3C; $n=3-5$; two-way ANOVA: $\left.\mathrm{F}_{(1,46)}=0.0056, P=0.9405\right)$. Thus, unlike LC, desensitization of opioid receptors on KF neurons was not enhanced in slices from morphine-treated rats.

Cellular Tolerance. Chronic morphine treatment leads to the development of cellular tolerance in LC neurons (Christie et al., 1987; Levitt and Williams, 2012). Cellular tolerance in $\mathrm{KF}$ neurons was investigated in slices from naïve, vehicletreated, or morphine-treated rats $(50 \mathrm{mg} / \mathrm{kg}$ per day for 6-7 days) that had been incubated for at least 2 hours in morphine-free solution. A saturating concentration of $\mathrm{ME}$ $(30 \mu \mathrm{M})$ produced the same-amplitude currents in slices from naïve and morphine-treated rats [naïve $=80 \pm 6 \mathrm{pA}(n=38)$; morphine-treated $=80 \pm 12 \mathrm{pA}(n=13) ; P=0.8854$, MannWhitney test]. The percentage of neurons with opioidmediated currents was similar in slices from vehicle- and morphine-treated rats (vehicle-treated 12/18 neurons $=67 \%$; morphine-treated 23/36 neurons $=64 \%$ ).

In opioid-sensitive KF neurons, bath perfusion of the GABA-B receptor agonist baclofen $(30 \mu \mathrm{M})$ also produced an outward current (Fig. 4A). The amplitude of baclofenmediated currents was not significantly different in slices from naïve, vehicle-treated, or morphine-treated rats [naïve $=$ $69 \pm 7 \mathrm{pA}(n=35)$; vehicle-treated $=78 \pm 14(n=9)$; morphine-treated $=73 \pm 8 \mathrm{pA}(n=16) ; P>0.05$, KruskalWallis test, Dunn's multiple comparisons]. In slices from naïve rats, the amplitude of the baclofen-mediated current was positively correlated with the amplitude of current produced by a subsaturating concentration of ME (300 nM) (Fig. 4B; linear regression: $r^{2}=0.77 ; n=35$ ). Therefore, the ME-mediated current was normalized to the baclofenmediated current for comparisons between cells. The current produced by ME (300 nM) was not different in morphinetreated rats compared with naïve rats or vehicle-treated rats [Fig. 4C; naïve $=78 \% \pm 4 \%$ of baclofen $(n=31)$; vehicletreated $=78 \% \pm 8 \%$ of baclofen $(n=7)$; morphine-treated $=$ $78 \% \pm 6 \%$ of baclofen $(n=16) ; P>0.05$, one-way ANOVA and Tukey's post-test]. 
A KF neuron, morphine-treated rat (MTR)

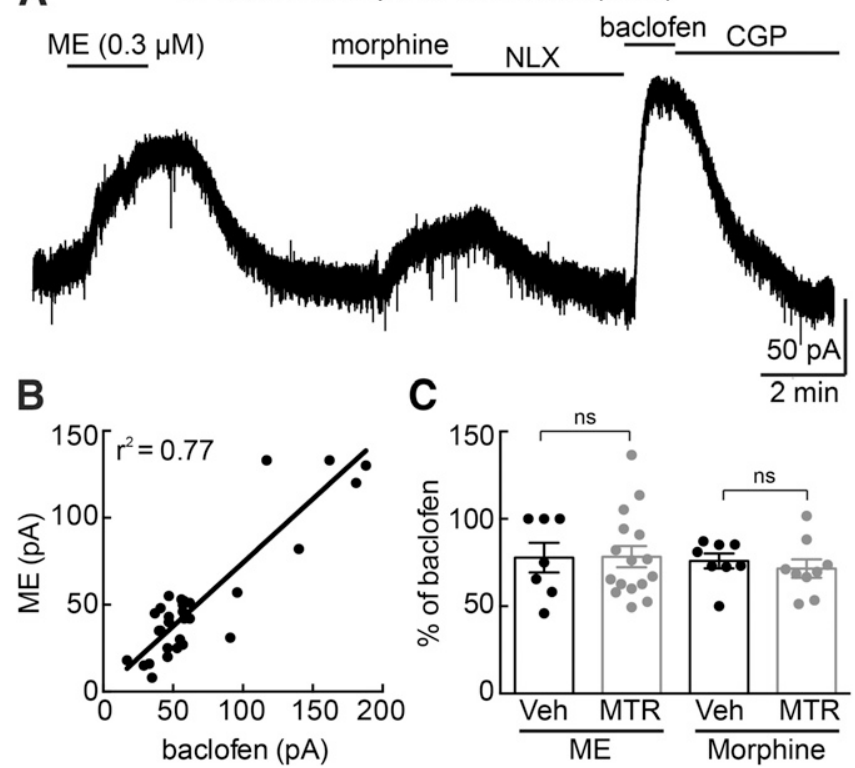

Fig. 4. Lack of cellular tolerance in KF neurons. (A) Whole-cell voltageclamp recording from a $\mathrm{KF}$ neuron in a slice from a morphine-treated (50 mg/kg per day, 6-7 days) rat. Opioid agonists $\mathrm{ME}(0.3 \mu \mathrm{M})$ and morphine $(1 \mu \mathrm{M})$, and GABA-B agonist baclofen $(30 \mu \mathrm{M})$ produced outward currents. Agonists that wash slowly were reversed by antagonists naloxone (NLX; $1 \mu \mathrm{M}$ ) and CGP55845 (CGP; $300 \mathrm{nM}$ ). (B) Correlation of the amplitude of current produced by baclofen $(30 \mu \mathrm{M})$ and $\mathrm{ME}(0.3 \mu \mathrm{M})$ in neurons from naïve rats. $R^{2}=0.77$ by linear regression. (C) ME-mediated $(0.3 \mu \mathrm{M})$ and morphine-mediated $(1 \mu \mathrm{M})$ currents were normalized to the amplitude of current produced by baclofen $(30 \mu \mathrm{M})$. The amplitude of current was not different between vehicle-treated (Veh) and morphine-treated rats for morphine ( $1 \mu \mathrm{M} ; P=0.5177$, Mann-Whitney test) or ME $(0.3 \mu \mathrm{M}$; $P=0.9740$, Mann-Whitney test). Line and error are the mean \pm S.E.M. Scatter shows individual data points (one neuron per slice). ns, not significant.

Morphine is a partial agonist in KF neurons (Levitt et al., 2015) and was used as a sensitive measure to determine the extent of cellular tolerance. The current produced by bath perfusion of a subsaturating concentration of morphine $(1 \mu \mathrm{M})$ was similar in slices from naïve, vehicle-treated, and morphine-treated rats [Fig. 4C; naïve $=62 \% \pm 8 \%$ of baclofen $(n=7)$; vehicle-treated $=$ $76 \% \pm 4 \%$ of baclofen $(n=8)$; morphine-treated $=72 \% \pm 5 \%$ of baclofen $(n=9) ; P>0.05$, one-way ANOVA and Tukey's posttest]. Thus, using both ME and morphine as an indicator, there was no evidence of opioid receptor tolerance on KF neurons.

\section{Discussion}

The main finding of this study was that, compared with LC neurons, prolonged activation of mu opioid receptors on $\mathrm{KF}$ neurons resulted in less desensitization. Manipulations that have been shown to enhance desensitization in LC neurons failed to alter desensitization in KF neurons. Desensitization and long-lasting cellular tolerance can be distinguished and are likely mediated by different mechanisms (Levitt and Williams, 2012). Cellular tolerance was not evident in KF neurons from morphine-treated rats. The lack of tolerance occurred even when using a subsaturating concentration of morphine, which is a sensitive assay for tolerance.

Somatodendritic mu opioid receptors on neurons in several areas, including LC (Harris and Williams, 1991; Alvarez et al., 2002; Blanchet and Lüscher, 2002; Bailey et al., 2004, 2009a,b; Virk and Williams, 2008; Quillinan et al., 2011; Arttamangkul et al., 2012; Dang et al., 2012; Williams, 2014; Lowe et al., 2015), periaqueductal gray (Ingram et al., 2008), hypothalamic proopiomelanocortin (POMC) (Pennock et al., 2012), and ventral tegmental area (VTA) (Lowe and Bailey, 2015), desensitize to various degrees. Desensitization of somatodendritic opioid receptors on $\mathrm{KF}$ neurons was less than LC neurons (directly compared here) and less than previously reported for LC, POMC neurons, or VTA dopamine neurons (Bailey et al., 2003; Pennock et al., 2012; Lowe and Bailey, 2015). The results in the $\mathrm{KF}$ are more similar to the lack of desensitization of presynaptic opioid receptors in LC, periaqueductal gray, POMC, and VTA (Blanchet and Lüscher, 2002; Fyfe et al., 2010; Pennock et al., 2012; Lowe and Bailey, 2015). The mechanism underlying the differential regulation of desensitization of preand postsynaptic receptors is unknown. The KF could serve as a tool to identify kinases or other signaling molecules that mediate acute opioid receptor desensitization. The additional lack of cellular tolerance in $\mathrm{KF}$ indicates either a lack of other factors that mediate cellular tolerance or that desensitization necessarily precedes cellular tolerance.

Mechanisms of Desensitization. The precise mechanisms that cause opioid receptor desensitization are not completely known, although many have been proposed (Williams et al., 2013). Evidence suggests that phosphorylation of the C-terminal tail of the mu opioid receptor is necessary for desensitization (Birdsong et al., 2015; Yousuf et al., 2015). However, the kinase(s) responsible is not known. Leading candidates are GRK2 and 3 (Lowe et al., 2015). The enhancement of desensitization observed in LC neurons after morphine treatment was absent in mice lacking $\beta$-arrestin 2 or with inactive GRK2 (Quillinan et al., 2011). The lack of this morphine-induced enhancement of desensitization in $\mathrm{KF}$ neurons indicates that $\mathrm{KF}$ neurons may have reduced levels of $\beta$-arrestin 2 and/or GRK2/3.

Activation of PKC enhances desensitization of the opioidmediated current, but this may be independent of phosphorylation of the receptor itself (Arttamangkul et al., 2015; Yousuf et al., 2015). In the LC, the enhancement of opioid-mediated desensitization appears to be specifically due to $\mathrm{PKC} \alpha$ (Bailey et al., 2009a,b). PKC can also reduce GIRK activity directly (Stevens et al., 1999; Mao et al., 2004; Adney et al., 2015). The KF highly expresses PKC $\gamma$ (Lein et al., 2007), which could mediate the heterologous reduction in GIRK current after $\mathrm{PDBu}$, but does not enhance opioid-mediated desensitization. PKC-dependent tolerance may occur in other places in the respiratory network, since tolerance to morphine-induced respiratory depression can be reversed by PKC inhibition in awake mice (Withey et al., 2017).

Amplitude of Current Does Not Explain Resistance to Desensitization. The difference in desensitization between LC and KF neurons is not likely due to differences in the amplitude of GIRK current produced by ME. There was no correlation between amplitude of current and amount of desensitization in KF or LC neurons (Figs. 1E and 2D), similar to previous reports on LC neurons (Virk et al., 2009). In the LC, when opioid currents were artificially reduced using an irreversible opioid antagonist, then smaller amplitude currents were correlated with greater (rather than smaller) apparent amounts of desensitization (Virk et al., 2009). Finally, the KF has a level of receptor reserve similar to LC based on the $300 \mathrm{nM} \mathrm{ME} / 30 \mu \mathrm{M}$ ME ratio and the observation that morphine is a partial agonist (Levitt et al., 2015).

Physiologic Relevance. Circulating concentrations of morphine following systemic treatment vary widely. In a report 
on cancer patients receiving continuous infusion of morphine sulfate, steady-state plasma morphine concentrations were $267 \mathrm{nM}$ to $105 \mu \mathrm{M}$ ( $n=8$; median $=479 \mathrm{nM}$ ) (Portenoy et al., 1991). In a report of heroin overdoses, total morphine levels ranged from $35 \mathrm{nM}$ to $17 \mu \mathrm{M}(n=234)$, with significant overlap between fatal and nonfatal cases (Meissner et al., 2002).

The chronic morphine treatment strategy used in this study creates a circulating morphine concentration of $1 \mu \mathrm{M}$ (Quillinan et al., 2011) and was sufficient to induce desensitization and tolerance of LC neurons (Levitt and Williams, 2012). This concentration is submaximal, but above the $\mathrm{EC}_{50}$ for morphine to activate GIRK currents in $\mathrm{KF}$ neurons $\left[\mathrm{EC}_{50}=0.4 \mu \mathrm{M}\right.$; Levitt et al. (2015)]. In KF neurons from morphine-treated rats, there was no tolerance at this clinically relevant concentration of morphine ( $1 \mu \mathrm{M})$. Thus, $\mathrm{KF}$ neurons would remain sensitive to morphine during dose escalation and could contribute to the reduced (but not absent) development of tolerance to the lifethreating respiratory depressant effects of opioids. Whether opioid receptors on neurons in respiratory nuclei distinct from $\mathrm{KF}$ develop tolerance remains to be determined.

\section{Acknowledgments}

The authors thank Dr. John Bissonnette for helpful discussion and feedback during manuscript preparation.

\section{Authorship Contributions}

Participated in research design: Levitt, Williams.

Conducted experiments: Levitt.

Performed data analysis: Levitt.

Wrote or contributed to the writing of the manuscript: Levitt, Williams.

\section{References}

Adney SK, Ha J, Meng X-Y, Kawano T, and Logothetis DE (2015) A critical gating switch at a modulatory site in neuronal Kir3 channels. $J$ Neurosci 35:14397-14405. Alvarez VA, Arttamangkul S, Dang V, Salem A, Whistler JL, Von Zastrow M, Grandy DK, and Williams JT (2002) mu-Opioid receptors: ligand-dependent activation of potassium conductance, desensitization, and internalization. J Neurosci 22:5769-5776.

Arttamangkul S, Birdsong W, and Williams JT (2015) Does PKC activation increase the homologous desensitization of $\mu$ opioid receptors? Br J Pharmacol 172:583-592.

Arttamangkul S, Lau EK, Lu HW, and Williams JT (2012) Desensitization and trafficking of $\mu$-opioid receptors in locus ceruleus neurons: modulation by kinases. Mol Pharmacol 81:348-355.

Athanasos P, Smith CS, White JM, Somogyi AA, Bochner F, and Ling W (2006) Methadone maintenance patients are cross-tolerant to the antinociceptive effects of very high plasma morphine concentrations. Pain 120:267-275.

Bailey CP, Couch D, Johnson E, Griffiths K, Kelly E, and Henderson G (2003) Muopioid receptor desensitization in mature rat neurons: lack of interaction between DAMGO and morphine. $J$ Neurosci 23:10515-10520.

Bailey CP, Kelly E, and Henderson G (2004) Protein kinase C activation enhances morphine-induced rapid desensitization of mu-opioid receptors in mature rat locus ceruleus neurons. Mol Pharmacol 66:1592-1598.

Bailey CP, Llorente J, Gabra BH, Smith FL, Dewey WL, Kelly E, and Henderson G (2009a) Role of protein kinase C and mu-opioid receptor (MOPr) desensitization in tolerance to morphine in rat locus coeruleus neurons. Eur J Neurosci 29:307-318.

Bailey CP, Oldfield S, Llorente J, Caunt CJ, Teschemacher AG, Roberts L, McArdle CA, Smith FL, Dewey WL, Kelly E, et al. (2009b) Involvement of PKC alpha and G-protein-coupled receptor kinase 2 in agonist-selective desensitization of mu-opioid receptors in mature brain neurons. Br J Pharmacol 158:157-164.

Birdsong WT, Arttamangkul S, Bunzow JR, and Williams JT (2015) Agonist binding and desensitization of the $\mu$-opioid receptor is modulated by phosphorylation of the C-terminal tail domain. Mol Pharmacol 88:816-824.

Blanchet C and Lüscher C (2002) Desensitization of mu-opioid receptor-evoked potassium currents: initiation at the receptor, expression at the effector. Proc Natl Acad Sci USA 99:4674-4679.

Centers for Disease Control and Prevention (2016) Wide-ranging online data for epidemiological research (WONDER), CDC National Center for Health Statistics, Atlanta, GA

Christie MJ, Williams JT, and North RA (1987) Cellular mechanisms of opioid tolerance: studies in single brain neurons. Mol Pharmacol 32:633-638.

Dahan A, Sarton E, Teppema L, Olievier C, Nieuwenhuijs D, Matthes HW, and Kieffer BL (2001) Anesthetic potency and influence of morphine and sevoflurane on respiration in mu-opioid receptor knockout mice. Anesthesiology 94:824-832.

Dang VC, Chieng BC, and Christie MJ (2012) Prolonged stimulation of $\mu$-opioid receptors produces $\beta$-arrestin-2-mediated heterologous desensitization of $\alpha(2)$-adrenoceptor function in locus ceruleus neurons. Mol Pharmacol 82:473-480.

Dang VC and Williams JT (2004) Chronic morphine treatment reduces recovery from opioid desensitization. J Neurosci 24:7699-7706.
Emery MJ, Groves CC, Kruse TN, Shi C, and Terman GW (2016) Ventilation and the response to hypercapnia after morphine in opioid-naive and opioid-tolerant rats. Anesthesiology 124:945-957.

Fyfe LW, Cleary DR, Macey TA, Morgan MM, and Ingram SL (2010) Tolerance to the antinociceptive effect of morphine in the absence of short-term presynaptic desensitization in rat periaqueductal gray neurons. J Pharmacol Exp Ther 335:674-680.

Harris GC and Williams JT (1991) Transient homologous mu-opioid receptor desensitization in rat locus coeruleus neurons. J Neurosci 11:2574-2581.

Hill R, Lyndon A, Withey S, Roberts J, Kershaw Y, MacLachlan J, Lingford-Hughes A, Kelly E, Bailey C, Hickman M, et al. (2016) Ethanol reversal of tolerance to the respiratory depressant effects of morphine. Neuropsychopharmacology 41:762-773.

Ingram SL, Macey TA, Fossum EN, and Morgan MM (2008) Tolerance to repeated morphine administration is associated with increased potency of opioid agonists. Neuropsychopharmacology 33:2494-2504.

Lein ES, Hawrylycz MJ, Ao N, Ayres M, Bensinger A, Bernard A, Boe AF, Boguski MS, Brockway KS, Byrnes EJ, et al. (2007) Genome-wide atlas of gene expression in the adult mouse brain. Nature 445:168-176.

Levitt ES, Abdala AP, Paton JFR, Bissonnette JM, and Williams JT (2015) $\mu$ opioid receptor activation hyperpolarizes respiratory-controlling Kölliker-Fuse neurons and suppresses post-inspiratory drive. J Physiol 593:4453-4469.

Levitt ES and Williams JT (2012) Morphine desensitization and cellular tolerance are distinguished in rat locus ceruleus neurons. Mol Pharmacol 82:983-992.

Ling GS, Paul D, Simantov R, and Pasternak GW (1989) Differential development of acute tolerance to analgesia, respiratory depression, gastrointestinal transit and hormone release in a morphine infusion model. Life Sci 45:1627-1636.

Lowe JD and Bailey CP (2015) Functional selectivity and time-dependence of $\mu$-opioid receptor desensitization at nerve terminals in the mouse ventral tegmental area. Br J Pharmacol 172:469-481.

Lowe JD, Sanderson HS, Cooke AE, Ostovar M, Tsisanova E, Withey SL, Chavkin C, Husbands SM, Kelly E, Henderson G, et al. (2015) Role of G protein-coupled receptor kinases 2 and 3 in $\mu$-opioid receptor desensitization and internalization. $M o l$ Pharmacol 88:347-356

Mao J, Wang X, Chen F, Wang R, Rojas A, Shi Y, Piao H, and Jiang C (2004) Molecular basis for the inhibition of $\mathrm{G}$ protein-coupled inward rectifier $\mathrm{K}(+)$ channels by protein kinase C. Proc Natl Acad Sci USA 101:1087-1092.

Matthes HW, Maldonado R, Simonin F, Valverde O, Slowe S, Kitchen I, Befort K, Dierich A, Le Meur M, Dollé P, et al. (1996) Loss of morphine-induced analgesia, reward effect and withdrawal symptoms in mice lacking the mu-opioid-receptor gene. Nature 383:819-823.

Meissner C, Recker S, Reiter A, Friedrich HJ, and Oehmichen M (2002) Fatal versus non-fatal heroin "overdose": blood morphine concentrations with fatal outcome in comparison to those of intoxicated drivers. Forensic Sci Int 130:49-54.

Paronis CA and Woods JH (1997) Ventilation in morphine-maintained rhesus monkeys. II: Tolerance to the antinociceptive but not the ventilatory effects of morphine. J Pharmacol Exp Ther 282:355-362.

Paxinos G and Watson C (1998) The Rat Brain in Stereotaxic Coordinates, 4th ed, Academic Press, San Diego, CA.

Pennock RL, Dicken MS, and Hentges ST (2012) Multiple inhibitory G-protein coupled receptors resist acute desensitization in the presynaptic but not postsynaptic compartments of neurons. J Neurosci 32:10192-10200.

Portenoy RK, Foley KM, Stulman J, Khan E, Adelhardt J, Layman M, Cerbone DF, and Inturrisi CE (1991) Plasma morphine and morphine-6-glucuronide during chronic morphine therapy for cancer pain: plasma profiles, steady-state concentrations and the consequences of renal failure. Pain 47:13-19.

Prkic I, Mustapic S, Radocaj T, Stucke AG, Stuth EAE, Hopp FA, Dean C, and Zuperku EJ (2012) Pontine $\mu$-opioid receptors mediate bradypnea caused by intravenous remifentanil infusions at clinically relevant concentrations in dogs. J Neurophysiol 108:2430-2441.

Quillinan N, Lau EK, Virk M, von Zastrow M, and Williams JT (2011) Recovery from mu-opioid receptor desensitization after chronic treatment with morphine and methadone. J Neurosci 31:4434-4443.

Rudd RA, Aleshire N, Zibbell JE, and Gladden RM (2016) Increases in drug and opioid overdose deaths-United States, 2000-2014. MMWR Morb Mortal Wkly Rep 64:1378-1382. Stevens EB, Shah BS, Pinnock RD, and Lee K (1999) Bombesin receptors inhibit G protein-coupled inwardly rectifying $\mathrm{K}+$ channels expressed in Xenopus oocytes through a protein kinase C-dependent pathway. Mol Pharmacol 55:1020-1027.

Torrecilla M, Marker CL, Cintora SC, Stoffel M, Williams JT, and Wickman K (2002) G-protein-gated potassium channels containing Kir3.2 and Kir3.3 subunits mediate the acute inhibitory effects of opioids on locus ceruleus neurons. J Neurosci 22:4328-4334.

Virk MS, Arttamangkul S, Birdsong WT, and Williams JT (2009) Buprenorphine is a weak partial agonist that inhibits opioid receptor desensitization. $J$ Neurosci 29:7341-7348.

Virk MS and Williams JT (2008) Agonist-specific regulation of mu-opioid receptor desensitization and recovery from desensitization. Mol Pharmacol 73:1301-1308. Williams JT (2014) Desensitization of functional $\mu$-opioid receptors increases agonist off-rate. Mol Pharmacol 86:52-61.

Williams JT, Ingram SL, Henderson G, Chavkin C, von Zastrow M, Schulz S, Koch T, Evans CJ, and Christie MJ (2013) Regulation of $\mu$-opioid receptors: desensitization, phosphorylation, internalization, and tolerance. Pharmacol Rev 65:223-254.

Williams JT and North RA (1984) Opiate-receptor interactions on single locus coeruleus neurones. Mol Pharmacol 26:489-497.

Withey SL, Hill R, Lyndon A, Dewey WL, Kelly E, and Henderson G (2017) Effect of tamoxifen and brain-penetrant protein kinase $\mathrm{C}$ and c-Jun N-terminal kinase inhibitors on tolerance to opioid-induced respiratory depression in mice. J Pharmacol Exp Ther 361:51-59.

Yousuf A, Miess E, Sianati S, Du Y-P, Schulz S, and Christie MJ (2015) Role of phosphorylation sites in desensitization of $\mu$-opioid receptor. Mol Pharmacol 88:825-835.

Address correspondence to: Erica S. Levitt, Department of Pharmacology and Therapeutics, University of Florida, 1200 Newell Drive Box 100267, Gainesville, FL. E-mail: erica.levitt@ufl.edu 